\title{
The effect of some solutions on the vase life of star flowers
}

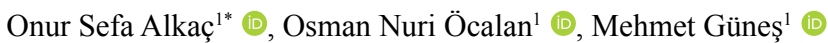 \\ ${ }^{1}$ Tokat Gaziosmanpaşa University Agricultural Faculty, Department of Horticulture, Tokat, Turkey.
}

\begin{abstract}
This study was carried out on the flowers of 'Le Castel' Dahlia (starflower) cultivated in Tokat Gaziosmanpaşa University Agricultural Research and Application Center in 2019. The study aimed to prolong the vase life of Dahlia flowers used as cut flowers. Deionized water (control), sucrose + deionized water, thyme oil, lavender oil, carvacrol, thymol, sodium hypochlorite, and gibberellic acid were used as vase solutions. The total vase solution uptake (g/stem), daily vase solution uptake (g/day fresh weight (FW)), proportional FW (\%) and vase life (day) parameters were determined based on Dahlia flowers that harvested at different harvest stages ( 3,4 and 5 layers). As a result; the most extended vase life was measured in the gibberellic acid treatment (8.22 days), the highest proportional fresh weight was measured in the carvacrol in the 6th day (139.78\%), the highest daily solution uptake was measured in the thyme oil in $0-2$ days $(11.7 \mathrm{~g} /$ day FW) and the highest total solution uptake was measured in the thyme oil (27.5 g/ stem). It was concluded that the vase life of earlier harvested flowers was longer than of late harvested.
\end{abstract}

Keywords: Dahlia sp., carvacrol, gibberellic acid, lavender oil, thymol.

\section{Resumo}

Efeito de algumas soluções na vida de vaso de dálias

Este estudo foi realizado com as flores da dália 'Le Castel' (starflower) cultivadas no Centro de Pesquisa e Aplicação Agrícola da Universidade Tokat Gaziosmanpaşa, em 2019. O estudo visa prolongar a vida útil dos vasos das flores Dahlia usadas como flores cortadas. Água deionizada (controle), sacarose + água deionizada, óleo de tomilho, óleo de lavanda, carvacrol, timol, hipoclorito de sódio e ácido giberélico usados como soluções em vasos. Os parâmetros captação total da solução do vaso (g haste $\left.{ }^{-1}\right)$, captação diária da solução do vaso ( $\mathrm{g}$ dia de peso fresco ${ }^{-1}$ ), peso proporcional fresco (\%) e vida do vaso (dias) foram determinados em flores de dália colhidas em diferentes estádios de colheita ( 3,4 e 5 camadas). Como um resultado a vida útil mais longa do vaso foi obsrvada no ácido giberélico (8,22 dias), o peso fresco proporcional mais alto foi medido no carvacrol no $6^{\circ}$ dia (139,78\%), a maior absorção diária da solução foi medida no óleo de tomilho em 0-2 dias $(11,7 \mathrm{~g}$ dia de peso fresco-1) e a maior absorção total da solução foi medida no óleo de tomilho $\left(27,5 \mathrm{~g}_{\text {haste }}{ }^{-1}\right)$. Concluiu-se que a vida útil dos vasos das flores colhidas mais cedo era mais longa do que da colheita tardia.

Palavras-chave: Dahlia., carvacrol, ácido giberélico, óleo de lavanda, timol.

\section{Introduction}

Dahlias are perennial plants with tuberous roots, though they are grown as annuals in some regions with cold winters. While some have herbaceous stems, others have stems which lignify in the absence of secondary tissue and resprout following winter dormancy, allowing further seasons of growth (Saar et al., 2003). Dahlias have various flower shapes such as straight, cactus, semi-cactus, anemone, pompom, ball, water lily, decorative, orchid, and peony. Flowers, apart from the shades of blue, offers a full range of colors, including all of the warm colors. In addition to this variation of color and shape, the fact that it is earlier in temperate climatic regions, but generally blooms from July to the first colds of autumn. Dahlia can also use as cut flowers. That is why the interest in this plant has increased in recent years. Photoperiod and average temperature have a crucial role in Dahlia cultivation. Because photoperiod significantly affects the size and the quality of the flower, and the number of flower buds, also in combination with temperature, on tuber development, shoot development, and flower formation (Romer, 2008). Dahlia needs 8-10 hours of sunlight per day to create abundant and highquality flowers. Also, the temperature should be between

"Corresponding author: onursefa.alkac5018@gop.edu.tr 
$18-24{ }^{\circ} \mathrm{C}$ during the day and $15-18^{\circ} \mathrm{C}$ at night (Alp, 2008). The vase life of Dahlia flowers is known to vary between 6 and 8 days under room conditions, but sufficient work has not been done in this area. However, it is necessary to conduct detailed studies to prolong the life of the vase, which is considered to be essential and potentially used as a cut flower.

Sucrose in vase solution treatment can increase the mechanical rigidity of the stem and induce cell wall thickening and lignification of vascular tissue (Jafarpour et al., 2015; Abu Seman and Mohd Rafdi, 2019). So, one of the main components of solutions used to determine vase life is sucrose. Dündar et al. (2018), in their study on the iris, cut flower, 'biocide,' and vase solutions containing $1 \%$ sucrose were used and indicated that three days more vase life was provided. In the study conducted by Özer et al. (2016) to determine the vase life of Orchis palustris flowers, the life of the vase was determined as 14.6 days in tap water with control solution, while in solutions containing $150 \mathrm{mg} \mathrm{L}^{-1} 8-\mathrm{HQ}, 100 \mathrm{mg} \mathrm{L}^{-1}$ $\mathrm{AgNO}_{3}, 80 \mathrm{mg} \mathrm{L}^{-1}$ sodium benzoate, $50 \mathrm{~g} \mathrm{~L}^{-1}$ sugar, 20 $\mathrm{mg} \mathrm{L}^{-1} \mathrm{AlSO}_{4}$, and $10 \mathrm{mg} \mathrm{L}^{-1}$ kinetin, the vase life has determined as 23.0 days. In another study conducted to determine the vase life of Freesia flowers, while the vase life of the control group determined as 6.33 days, the most extended vase life has obtained from 1-MCP (4 nl.L-1 + 3 hours) with 9.06 days (Zencirkıran, 2010). Mehraj et al. (2016) have concluded that sucrose-containing solutions both had a more excellent vase life than control and an increase in vase life. Vase life prolonged after applying different doses of $\mathrm{GA}_{3}$ and $\mathrm{BA}$, the vase life, fresh weight, solution uptake, membrane stability, and total soluble matter content of gerbera flowers kept in vase solution containing 2.5\% ethanol and 3\% sucrose (Danaee et al., 2011).

In this study; it was aimed to determine the effect of different harvest stages and solutions on the vase life of Dahlia (starflower), which has the potential to produce cut flowers and which has become popular.

\section{Material and Methods}

In the study, flowers of "Le Castel" Dahlia cultivated in the field of Agricultural Research and Application in Tokat Gaziosmanpaşa University were used as plant materials. The 3, 4, and 5 layer harvested flowers (Figure 1) were cut to $20 \mathrm{~cm}$ long and placed in vases capable of receiving 340 $\mathrm{mL}$ of the solution under room conditions $\left(21^{\circ} \mathrm{C} \pm 1\right)$. A total of 80 flowers were used in the study (Figure 2).

The beginning of the study was determined as 0 (zero) days, and the end of the study was determined as the day when $50 \%$ of the flower petals begin to wilt.
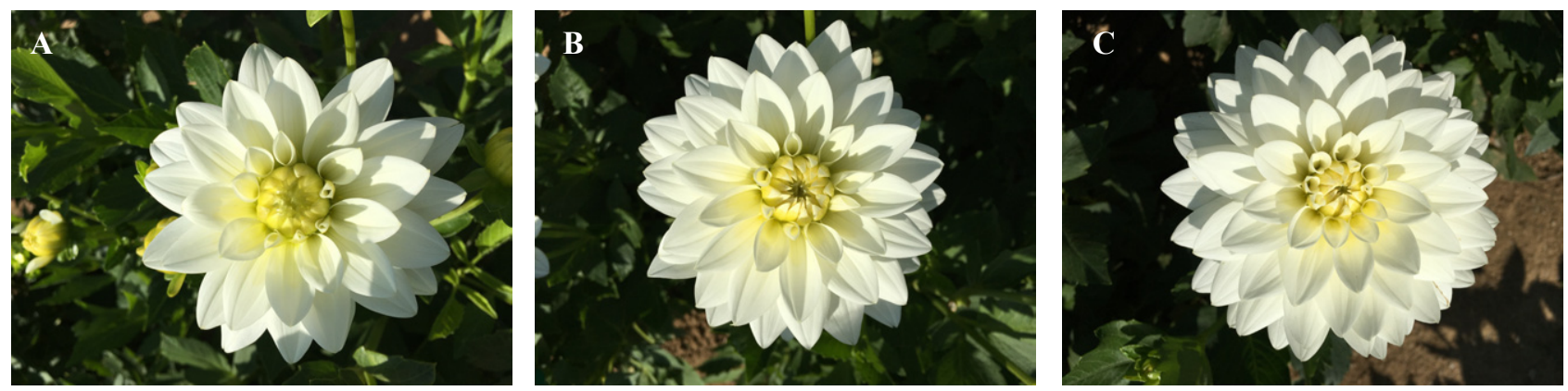

Figure 1. Flowers belonging to the "Le Castel" Dahlia cultivar harvested in 3 (A), 4 (B) and 5 (C) layers.

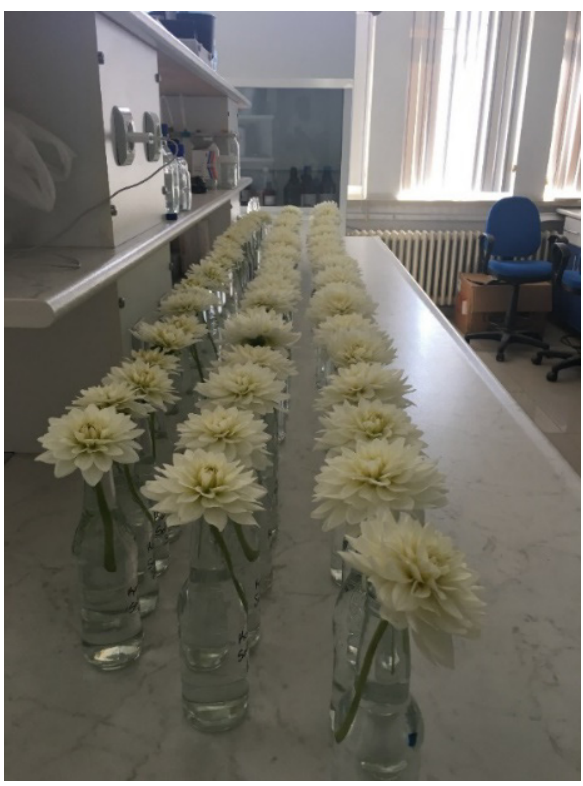

Figure 2. Dahlia flowers placed to vases in room conditions 
Total vase solution uptake (g/stem), daily vase solution uptake (g/day FW), proportional FW (\%), and vase life (day) (50\% of flower petals begin to wilt) parameters were examined with two days intervals. The treatments and concentrations used in the study were presented in the Table 1.
The trial was designed as a Completely Randomized Design with three replications. Data of all parameters were recorded daily. The obtained data were subjected to the variance of analysis (One-way ANOVA) (IBM SPSS Statistic 17.0 statistics program). Duncan multiple tests $(p<0.05)$ was used was for comparing means.

Table 1. Treatments and concentrations used as vase solutions

\begin{tabular}{|c|c|}
\hline Treatment & Concentration \\
\hline Deionized Water (DW) (Control) $(\mathrm{mL})$ & 340 \\
\hline Sucrose $(\%)+\mathrm{DW}$ & 4 \\
\hline Thyme Oil (mg/L) & 150 \\
\hline Lavender Oil (mg/L) & 150 \\
\hline Carvacrol (mg/L) & 150 \\
\hline Thymol (mg/L) & 150 \\
\hline Sodium Hypochlorite $(\mathrm{mg} / \mathrm{mL})$ & $0.5 / 340$ \\
\hline Gibberellic acid $(\mathrm{ppm})$ & 200 \\
\hline
\end{tabular}

\section{Results}

\section{Vase life}

In the study, the effect of different harvest time (phase) treatments on the life of the starflower's vase was insignificant $(p>0.05)$, but the effect of different vase solution treatments on the life of the vase was found significant $(\mathrm{p}>0.05)$ (Table 2$)$.

It was determined that the treatment of gibberellic acid had the highest ( 8.22 days) vase life, and the treatments of carvacrol, thymol and sodium hypochlorite had the lowest (6.89 days) on the vase life (Table 3 ).

Table 2. The effect of different layer numbers on Dahlia flower vase life (day)

\begin{tabular}{|c|c|}
\hline Number of Layers & Average \\
\hline 3 & $7.83 \pm 0.27$ \\
\hline 4 & $7.33 \pm 0.20$ \\
\hline 5 & $7.50 \pm 0.22$ \\
\hline Significance coefficient & 0.296 \\
\hline
\end{tabular}

\pm : Standard deviation

Table 3. The effect of different solutions on the life of Dahlia flower's vase (day)

\begin{tabular}{|c|c|}
\hline Treatments & Average \\
\hline DW (Control) & $8.00 \pm 0.00 \mathrm{ab}$ \\
\hline Sucrose + DW & $7.56 \pm 2.19 \mathrm{ab}$ \\
\hline Thyme Oil & $8.00 \pm 0.00 \mathrm{ab}$ \\
\hline Lavender Oil & $8.00 \pm 0.00 \mathrm{ab}$ \\
\hline Carvacrol & $6.89 \pm 1.05 \mathrm{~b}$ \\
\hline Thymol & $6.89 \pm 1.05 \mathrm{~b}$ \\
\hline Sodium Hypochlorite & $6.89 \pm 1.05 \mathrm{~b}$ \\
\hline Gibberellic acid & $8.22 \pm 0.67 \mathrm{a}$ \\
\hline Significance coefficient & $0.012 *$ \\
\hline
\end{tabular}

*: Statistically significant at $\mathrm{p}<0.05$ level. \pm : Standard deviation 


\section{Proportional fresh weight}

When the different harvest stages (number of layers) were examined, the values obtained on the $2^{\text {nd }}, 8^{\text {th }}, 10^{\text {th }}$, and $12^{\text {th }}$ days were found statistically insignificant $(\mathrm{p}>0.05)$. When the values on the $4^{\text {th }}$ and $6^{\text {th }}$ days examined, it was found statistically significant that the proportion of fresh weight values increased as the number of layers increased $(\mathrm{p}<0.05)$. The 5 layer flowers had the highest proportional fresh weight $(99.69 \%-129.46 \%)$, and the lowest proportional fresh weight measurements were determined in 3 layer flowers (79.96\%-99.95\%) compared to other layers. From the $6^{\text {th }}$ day, it was determined that the proportional fresh weight decreases, and the deaths of the plants occurred (Table 4).

Table 4. The effect of different layer numbers on proportional fresh weight in starflower (\%)

\begin{tabular}{|c|c|c|c|c|c|c|}
\hline Number of Layer & $\mathbf{2}^{\text {nd }} \mathbf{d a y}$ & $\mathbf{4}^{\text {th }} \mathbf{d a y}$ & $\mathbf{6}^{\text {th }} \mathbf{d a y}$ & $\mathbf{8}^{\text {th }} \mathbf{d a y}$ & $\mathbf{1 0}^{\text {th }} \mathbf{d a y}$ \\
\hline $\mathbf{3}$ & $77.12 \pm 2.20$ & $79.96 \pm 2.82 \mathrm{~b}$ & $99.95 \pm 4.31 \mathrm{~b}$ & $91.52 \pm 11.96$ & $9.86 \pm 7.15$ \\
\hline $\mathbf{4}$ & $82.89 \pm 4.81$ & $89.49 \pm 6.24 \mathrm{ab}$ & $116.79 \pm 9.79 \mathrm{ab}$ & $80.43 \pm 12.74$ & .00 \\
\hline $\mathbf{5}$ & $91.58 \pm 24.13$ & $99.69 \pm 6.37 \mathrm{a}$ & $129.46 \pm 9.23 \mathrm{a}$ & $103.6 \pm 14.79$ & .00 \\
\hline $\begin{array}{c}\text { Significance } \\
\text { coefficient }\end{array}$ & 0.054 & $0.041^{\text {th }}$ & $0.043^{*}$ & 0.468 & 0.402 \\
\hline
\end{tabular}

*: Statistically significant at $\mathrm{p}<0.05$ level. $\quad \pm$ : Standard deviation

When the effect of different vase solution treatments on proportional fresh weight were examined, the difference between the findings obtained on the $2^{\text {nd }}, 4$ th, $10^{\text {th }}$, and $12^{\text {th }}$ days were not significant $(\mathrm{p}>0.05)$. The difference between the results obtained on the $6^{\text {th }}$ and the $8^{\text {th }}$ days were found significant $(\mathrm{p}<0.01)$. When the proportional fresh weight data were obtained on the 6th day examined, the highest proportional fresh weight values were obtained in the vase solution containing sodium hypochlorite $(139.6 \%)$ and the vase solution containing carvacrol $(139.78 \%)$. The lowest proportional fresh weight ratio was determined in the vase solution containing gibberellic acid (85.56\%). When the data were obtained on the 8th day examined, the highest proportional fresh weight was measured in the vase solution containing lavender oil (133.53\%), and the lowest proportional fresh weight was measured in the vase solution containing thymol (52\%) (Table 5).

Table 5. The effect of different vase solutions on proportional fresh weight in starflower (\%)

\begin{tabular}{|c|c|c|c|c|c|c|}
\hline Treatment & $2^{\text {nd }}$ day & $4^{\text {th }}$ day & $6^{\text {th }}$ day & $8^{\text {th }}$ day & $10^{\text {th }}$ day & $12^{\text {th }}$ day \\
\hline DW & $81.47 \pm 5.61$ & $81.35 \pm 6.29$ & $98.79 \pm 7.81 \mathrm{bcd}$ & $128.7 \pm 9.94 \mathrm{a}$ & .00 & .00 \\
\hline Sucrose + DW & $88.41 \pm 11.00$ & $101.16 \pm 14.46$ & $136.51 \pm 21.41 \mathrm{ab}$ & $54.31 \pm 23.00 \mathrm{c}$ & .00 & .00 \\
\hline Thyme Oil & $78.15 \pm 5.18$ & $77.85 \pm 5.29$ & $94.96 \pm 7.50 \mathrm{~cd}$ & $125.56 \pm 10.54 a$ & .00 & .00 \\
\hline Lavender Oil & $81.32 \pm 3.14$ & $81.3 \pm 3.75$ & $101.85 \pm 5.00 \mathrm{abcd}$ & $133.53 \pm 6.86 a$ & .00 & .00 \\
\hline Carvacrol & $88.38 \pm 11.47$ & $105.23 \pm 14.99$ & $139.78 \pm 20.00 \mathrm{a}$ & $56.38 \pm 24.10 \mathrm{c}$ & .00 & .00 \\
\hline Thymol & $82.62 \pm 2.51$ & $91.15 \pm 3.61$ & $126.17 \pm 8.66 \mathrm{abc}$ & $52 \pm 26.25 c$ & .00 & .00 \\
\hline $\begin{array}{c}\text { Sodium } \\
\text { Hypochlorite }\end{array}$ & $90.78 \pm 7.28$ & $101.94 \pm 7.46$ & $139.6 \pm 10.81 \mathrm{a}$ & $65.46 \pm 26.00 b c$ & .00 & .00 \\
\hline Gibberellic acid & $79.79 \pm 6.07$ & $77.7 \pm 5.76$ & $85.56 \pm 6.69 d$ & $118.85 \pm 11.64 \mathrm{ab}$ & .00 & .00 \\
\hline $\begin{array}{l}\text { Significance } \\
\text { coefficient }\end{array}$ & .889 & .112 & $.005 * *$ & $.001 * *$ & .198 & .440 \\
\hline
\end{tabular}

*: Statistically significant at $\mathrm{p}<0.05, * *$ : $\mathrm{p}<0.01$ level. $\quad \pm$ : Standard deviation, DW: Deionized Water

\section{Daily vase solution uptake}

There was no statistically significant effect on daily vase solution uptake ( $p>0.05)$ when the different harvest stage (number of layers) treatments were examined in Table 6, there was no statistically significant effect on daily vase solution uptake $(p>0.05)$. When the effect of different vases solution treatments were examined, the effect of starflower on daily vase solution uptake was statistically significant at values measured in 2-4, 4-6, and 6-8 days $(\mathrm{p}<0.01)$. When we look at the data obtained in 2-4 days, the highest daily vase solution uptake was measured in the vase solution treatment containing thyme

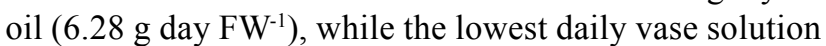
uptake was determined in the vase solution treatment containing carvacrol $\left(2.45 \mathrm{~g}^{\text {day }} \mathrm{FW}^{-1}\right)$. When the data received in 4-6 days are analyzed, the highest daily vase solution uptake was determined in the treatment of vase solution containing gibberellic acid (5.42 $\left.\mathrm{g}_{\text {day }} \mathrm{FW}^{-1}\right)$, 
while the lowest daily vase solution uptake was obtained

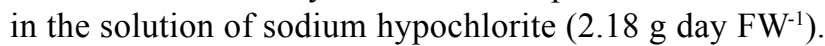
When the values measured in 6-8 days were examined, the highest daily vase solution uptake was determined in the vase solution treatment containing thyme oil (4.80 g day $\mathrm{FW}^{-1}$ ), while the lowest daily vase solution uptake was determined in the vase solution treatment containing thymol (1.10 g/day FW) (Table 7).

Table 6. The effect of different layers on daily vase solution uptake in Starflower (Dahlia sp.) (g / day fresh weight)

\begin{tabular}{|c|c|c|c|c|c|c|}
\hline $\begin{array}{c}\text { Number of } \\
\text { layer }\end{array}$ & $0-2^{\text {nd }}$ day & $2-4^{\text {nd }}$ day & $4-6^{\text {nd }}$ day & $6-8^{\text {nd }}$ day & $8-10^{\text {nd }}$ day & $10-12^{\text {nd }}$ day \\
\hline 3 & $9.74 \pm 0.27$ & $3.93 \pm 0.34$ & $3.11 \pm 0.26$ & $2.43 \pm 0.46$ & $0.11 \pm 0.08$ & .00 \\
\hline 4 & $10.28 \pm 0.34$ & $4.11 \pm 0.38$ & $3.49 \pm 0.39$ & $2.63 \pm 0.42$ & .00 & .00 \\
\hline 5 & $11.15 \pm 0.55$ & $5.12 \pm 0.43$ & $4.36 \pm 0.45$ & $3.33 \pm 0.55$ & .00 & .00 \\
\hline $\begin{array}{c}\text { Significance } \\
\text { coefficient }\end{array}$ & .055 & .073 & .063 & .389 & .528 & .373 \\
\hline
\end{tabular}

*: Statistically significant at $\mathrm{p}<0.05, * *$ : $\mathrm{p}<0.01$ level. $\quad \pm$ : Standard deviation

Table 7. The effect of different vase solutions on daily vase solution uptake in starflower (g / day fresh weight)

\begin{tabular}{|c|c|c|c|c|c|c|}
\hline Treatment & $0-2^{\text {nd }}$ day & $2-4^{\text {nd }}$ day & $4-6^{\text {nd }}$ day & $6-8^{\text {nd }}$ day & $8-10^{\text {nd }}$ day & $10-12^{\text {nd }}$ day \\
\hline DW & $11.1 \pm 0.94$ & $5.29 \pm 0.21 \mathrm{ab}$ & $4.55 \pm 0.28 \mathrm{a}$ & $4.43 \pm 0.22 \mathrm{a}$ & .00 & .00 \\
\hline Sucrose + DW & $10.45 \pm 0.74$ & $3.48 \pm 0.82 \mathrm{c}$ & $2.26 \pm 0.52 b$ & $0.98 \pm 0.40 \mathrm{c}$ & .00 & .00 \\
\hline Thyme Oil & $11.7 \pm 0.68$ & $6.28 \pm 0.70 \mathrm{a}$ & $5.41 \pm 0.73 \mathrm{a}$ & $4.8 \pm 0.83 \mathrm{a}$ & .00 & .00 \\
\hline Lavender Oil & $10.91 \pm 0.31$ & $5.41 \pm 0.12 \mathrm{ab}$ & $4.27 \pm 0.31 \mathrm{a}$ & $4.01 \pm 0.34 \mathrm{a}$ & .00 & .00 \\
\hline Carvacrol & $9.55 \pm 0.90$ & $2.45 \pm 0.63 \mathrm{c}$ & $2.32 \pm 0.50 \mathrm{~b}$ & $2.1 \pm 1.13 \mathrm{bc}$ & .00 & .00 \\
\hline Thymol & $10.67 \pm 0.33$ & $3.88 \pm 0.42 b c$ & $2.8 \pm 0.29 b$ & $1.1 \pm 0.56 \mathrm{c}$ & .00 & .00 \\
\hline Sodium Hypochlorite & $8.75 \pm 0.63$ & $2.87 \pm 0.45 \mathrm{c}$ & $2.18 \pm 0.44 \mathrm{~b}$ & $1.32 \pm 0.66 \mathrm{c}$ & .00 & .00 \\
\hline Gibberellic acid & $9.99 \pm 0.27$ & $5.42 \pm 0.19 \mathrm{ab}$ & $5.42 \pm 0.48 \mathrm{a}$ & $3.6 \pm 0.47 \mathrm{ab}$ & .00 & .00 \\
\hline $\begin{array}{c}\text { Significance } \\
\text { coefficient }\end{array}$ & .060 & $.000 * * *$ & $.000 * * *$ & $.000 * * *$ & .419 & .440 \\
\hline
\end{tabular}

Statistically significant at *: $\mathrm{p}<0.05$ level, ${ }^{* *}: \mathrm{p}<0.01$ level, ${ }^{* * *}$ : $<0.001$ level. $\quad \pm$ : Standard deviation, DW: Deionized Water

\section{Total vase solution uptake}

There was no statistically significant effect on total vase solution uptake $(\mathrm{p}>0.05)$ when different harvest stage (number of layers) treatments were examined in Table 8 , there was no statistically significant effect on total vase solution uptake $(\mathrm{p}>0.05)$. However, as the number of layers increased, it was observed that total vase solution uptake increased.
When the effect of different vase solutions on total vase solution uptake was examined, it has been found statistically significant $(\mathrm{p}<0.01)$. When comparing between the treatments, the highest total vase solution uptake was measured in the vase solution containing thyme oil $(27.5$ $\mathrm{g}$ branch $\left.^{-1}\right)$. The lowest total vase solution uptake was determined in vase solution containing sodium hypochlorite $\left(13.87 \mathrm{~g} \mathrm{branch}^{-1}\right)($ Table 9).

Table 8. The effect of different layer numbers on the total vase solution uptake in starflower plant (g/branch)

\begin{tabular}{|c|c|}
\hline Number of layer & Average \pm Standard Error \\
\hline 3 & $18.21 \pm 1.04$ \\
\hline 4 & $22.19 \pm 1.54$ \\
\hline 5 & $22.94 \pm 1.68$ \\
\hline Significance coefficient & 0.052 \\
\hline
\end{tabular}


Table 9. The effect of different vase solutions on the total vascular solution uptake in starflower plant (g/branch)

\begin{tabular}{|c|c|}
\hline Treatment & Average \\
\hline DW & $23.31 \pm 1.32 \mathrm{ab}$ \\
\hline Sucrose + DW & $22.74 \pm 3.39 \mathrm{ab}$ \\
\hline Thyme Oil & $27.5 \pm 2.82 \mathrm{a}$ \\
\hline Lavender Oil & $23.85 \pm 0.60 \mathrm{ab}$ \\
\hline Carvacrol & $16.08 \pm 2.70 \mathrm{c}$ \\
\hline Thymol & $17.76 \pm 1.35 \mathrm{c}$ \\
\hline Sodium Hypochlorite & $13.87 \pm 1.08 \mathrm{c}$ \\
\hline Gibberellic acid & $23.8 \pm 1.24 \mathrm{ab}$ \\
\hline Significance coefficient & 0.00 \\
\hline *: Statistically significant at $\mathrm{p}<0.05, * *: \mathrm{p}<0.01$ level. \\
\hline :: Standard deviation
\end{tabular}

\section{Discussion}

One of the most critical factors affecting the vase life of cut flowers is harvest time or ripening stage. When the effect of early harvested flowers on the vase life examined, it has been seen that, although there is no statistically significant difference, the life of the flowers harvested in the early maturity stage increases the vase life and the flower quality lasts longer than the late-harvested flowers. Since the concentration of sodium hypochlorite was high in the study, it caused premature deaths in starflower, thus negatively affecting on the total vase solution uptake and daily vase solution uptake. It was determined that the solution uptake was higher in the plants (4 and 5 layer star flowers) whose harvest stage is progressing. During the life of vase, the proportional fresh weight and vase solution uptakes on the upgrade at first, and then weight and solution uptakes on the wane with the closure of the stem of the flower branch according to the solution contents. When the parameters of vase life, proportional fresh weight, daily vase solution uptake, and total vase solution uptake were examined, it concluded that essential oils, especially thyme oil and lavender oil, had significant effects.

The most active monoterpenoid phenols of essential oils are known thyme oil and lavender oil (Dhifi et al., 2016), which found useful to increase the vase life of some cut flowers (Thakur et al., 2014). These results may be due to the role of thyme oil and lavender oil as antimicrobial agents (Memar et al., 2017), and they might have reduced xylem blockage and increased solution uptake, which may improve the vase life and relatively fresh weight. A positive correlation is stated between vase life, solution uptake, and relatively fresh weight in any kind of researches (Alaey et al. 2011; Amini et al., 2016). Salehi Salmi et al. (2018), in their study on cut roses, indicated that essential oils cause early flower opening and senescence of flowers. However, in our study, it is concluded that it impediments senescence and increases the life of the vase in the flowers harvested early since it determines its effect in its layers. Sucrose acts as osmolytes and source of energy that plays a vital role to preserve the quality of cut flowers (Abu Seman and Mohd Rafdi, 2019). Mehraj et al. (2016) in their study on Gerbera ( $G$. jamesonii) were used different sucrosecontaining solutions and has been reported that sucrosecontaining solutions maintain visual quality criteria and increase in the life of the vase. The combination of salicylic acid and sucrose also led to a significant reduction in the respiration rate and alleviated the moisture stress of cut roses to improve the vase life (Bayat and Aminifard, 2017). So, it would be useful to add sucrose to vases solutions or to use it with other essential oils. Dündar et al. (2018) used vases solutions containing 'biocide' in their study on Iris cut flower and had reported that they provided three days more vase life. Zencirkıran (2010), used chemicals that inhibit the synthesis of ethylene in his study in Freesia had reported an increase in the life of the vase.

\section{Conclusions}

It was concluded that the use of 'biocide' is essential for reducing the microorganisms such as bacteria, fungi and mold formed in the solutions used in the study and that new studies are needed based on the idea that ethylene inhibitors can have a positive effect on the postharvest performance of starflower.

\section{Author Contribution}

OSA: experiment idea, installation of the experiment, field analysis, data collection and analysis, ONÖ: installation of the experiment, analysis and interpretation of data, critical review of the article. MG: advisor of work, preparation and writing of the article, critical review, interpretation, translation, approval of the final version of the article. 


\section{References}

ABU SEMAN, H.H.; MOHD RAFDI, H.H. Effects of salicylic acid and sucrose solution on vase life of cut Antigonon leptopus inflorescences and their potential as cut flowers for flower arrangement. Universiti Malaysia Terenggan Journal of Undergraduate Research, v.1, n.1, p.80-91, 2019.

ALAEY, M.; BABALAR, M.; NADERI, R.; KAFI, M. Effect of pre and postharvest salicylic acid treatment on physio-chemical attributes in relation to vase-life of rose cut flowers. Postharvest Biology and Technology, v.61, p.91-94, 2011.

ALP, Ş. Yıldız çiçeği (Dahlia sp.) yetiştiriciliği, sınıflandırılması ve kullanımı [Dahlia (Dahlia sp.), breeding, classification and usage]. Bağbahçe Çevre Bahçe ve Çiçek Dergisi [Vineyards, Environment, Garden and Flower Magazine], p.16-18, 2008.

AMINI, S.; ARAB RAHEMI, M.; RAHIMI, A.R.; GARMAKHANY, A.D. Effect of thyme essential oil on vase life of two carnations (Dianthus caryophyllus L.) cultivars. Journal of Essential Oil Bearing Plants, v.1, n.3, p.734-742, 2016.

BAYAT, H.; AMINIFARD, M.H. Salicylic acid treatment extends the vase life of five commercial cut flowers. Electronic Journal of Biology, v.13, n.1, p.67- 72, 2017.

DANAEE, M.; ABDOSSI, V. Evaluation of the effect of plant growth substances on longevity of gerbera cut flowers cv. Sorbet. Iranian Journal of Plant Physiology, v.7, n.1, p.1943-1947, 2016.

DEMIRCIOĞLU, H.; DÜNDAR, Ö.; ÖZKAYA, O. Investigation of storage and vase life of narcissus (Narcissus tazetta subsp.) growing in Tuzla. V. Ornamental Plants Congress, v.2, p.573-580, 2013.

DHIFI, W; BELLILI, S; JAZI, S; BAHLOUL, N; MNIF, W. Essential Oils' Chemical characterization and investigation of some biological activities: a critical review. Medicines v.3, n.4, p.25-41, 2016. DOI: https://doi.org/10.3390/ medicines3040025.

DÜNDAR, Ö; DEMIRCIOĞLU, H; ÖZKAYA, O. Investigation of vase life of Iris cut flower in vase solution containing sucrose. Manas Journal of Agriculture Veterinary and Life Sciences, v.8, n.2, p.84-88, 2018.

JAFARPOUR, M.; GOLPARVAR, A.R.; ASKARIKHORASGANI, O.; AMINI, S. Improving postharvest flowers using natural and chemical preservatives. Journal of European Agriculture, v.16, n.2, p.199-211, 2015.
MEHRAJ, H.; SHIAM, I.H.; TAUFIQUE, T.; SHAMSUZZOHA, M.; JAMAL UDDIN, A.F.M. Effects of floral preservative solutions for vase life evaluation of Gerbera. Journal of Bioscience and Agriculture Research, v.9, n.02, p.804-811, 2016.

MEMAR, M.Y.; RAEI, P.; ALIZADEH, N.; AKBARI, A.; MASOUD, K.; HOSSEIN, S. Carvacrol, and thymol strong antimicrobial agents against resistant 1solates. Reviews in Medical Microbiology, v.28, n.2, p.63-68, 2017.

ÖZER, S.; YILMAZ, H.; IRMAK, M.; A; ZENGIN, M. The effect of different chemical mixtures on the vase life and some other properties of Orchis palustris. Iğdır University Journal of The Institute of Science and Technology, v.6, n.3, p.135-142, 2016.

ROMER, J. Growing dahlias. Iowa: Iowa State University, 2008. 2 p.

SAAR, D.E.; POLANS, N.O.; SØRENSEN, P.D. A phylogenetic analysis of the genus Dahlia (Asteraceae) based on internal and external transcribed spacer regions of nuclear ribosomal DNA. Systematic Botany, v.28, n.3, p.627-639, 2003.

SALEHI SALMI, M.R.; FALEHI HOSEINI, M.; HEIDARI, M.; DANESHVAR, M.H. Extending vase life of cut rose (Rosa hybrida L.) cv. Bacara by essential oils. Advances in Horticultural Science, v.32, n.1, p.61-69, 2018.

TANKER, N.; KOYUNCU, M.; COŞKUN, M. Pharmaceutical botanical. Ankara: University Faculty of Pharmacy Publications, 2007. 93p.

THAKUR, L.K.; ROY, S.; PRAJAPATI, R.; SINGH, M.K.; RAZA, S.K.; MANGAVE, B.D.; SINGH, A.; JHA, S. Development and evaluation of environment \& user-friendly turmeric oil emulsifiable concentrate (ec) formulations for postharvest quality and life in Rose cv. Poison. International Journal of Recent Scientific Research Research, v.5, n.1, p.178-185, 2014.

ZENCIRKIRAN, M. Effects of 1-MCP (1-methyl cyclopropane) and STS (silver thiosulphate) on the vase life of cut Freesia flowers. Scientific Research and Essays, v.5, n.17, p.2409-2412, 2010. 